\title{
Reduction of phosphorus concentration in mineral supplement on fertility rate, maternal ability and costs of beef cows reared in pastures of Urochloa decumbens
}

\author{
Rogério Magnoli Costa ${ }^{1}$ Elisa Helena Giglio Ponsano ${ }^{2}$ - Vinícius Carneiro de Souza ${ }^{3}$. \\ Pedro Malafaia ${ }^{4}$
}

Received: 13 October 2015 / Accepted: 1 December 2015 /Published online: 19 December 2015

(C) Springer Science+Business Media Dordrecht 2015

\begin{abstract}
Manufacturing and marketing of mineral mixtures with less than $40 \mathrm{~g} \mathrm{~kg}^{-1}$ phosphorus (P) is prohibited under Brazilian regulations, although scientific evidence rejects this recommendation. Considering the hypothesis that $\mathrm{P}$ levels in commercial mineral supplements can be reduced without affecting animal performance and health, the objective of this experiment was to evaluate the effects of reducing the concentration of $\mathrm{P}$ in the mineral supplement (from 40 to $18 \mathrm{~g} \mathrm{~kg}^{-1}$ ) of a herd of beef cows grazing tropical pastures of signal grass (Urochloa decumbens). The experiment was carried out in the savanna region of Mato Grosso do Sul, Brazil, during the years 2011 to 2013. Variables analyzed included pregnancy rate, calving interval, weight of calves at weaning, and cost of mineral supplementation. There were no changes in the reproductive parameters of the herd and the weight at weaning of the calves. However, the cost of mineral supplementation was significantly lower when the herd was supplemented with the mineral mix containing only $18 \mathrm{~g} \mathrm{~kg}^{-1} \mathrm{P}$. Phosphorus concentration of the forage was analyzed monthly during 1 year and averaged $1.9 \pm 0.45 \mathrm{~g} \mathrm{~kg}^{-1} \mathrm{DM}$. Thus, it appears possible to reduce $\mathrm{P}$ content and cost of mineral supplementation without any adverse effects on the health and productivity of beef cattle herds in the State of Mato Grosso do Sul. However, the final decision should be made based on the clinical-
\end{abstract}

Pedro Malafaia

malafaia_ufrrj@yahoo.com.br

1 Êxito Rural Consultoria em Pecuária, Av.Mário Covas 2747, Araçatuba, SP, Brazil

2 DAPSA, FMVA, UNESP, Araçatuba, SP 16050-680, Brazil

3 Departamento de Zootecnia, UNESP, Jaboticabal, SP 14884-900, Brazil

4 DNAP, IZ, UFRRJ, Seropédica-RJ, Brazil nutritional examination and by constant technical assistance to the farm.

Keywords Beef cattle $\cdot$ Cost of mineral supplementation . Phosphorus

\section{Introduction}

Brazil produces more than $85 \%$ of its slaughtered cattle raised on tropical pastures and the cow-calf system is located mainly in the areas of cerrado (savanna) and natural fields, characterized by low soil fertility. About $80 \%$ of Brazilian arable land has some limitation in $\mathrm{P}$ availability, which determines the need, to a great or less extent, of $\mathrm{P}$ supplementation to grazing animals, to ensure good health, performance, and economic viability of the farm (Malafaia et al. 2014). McDowell et al. (1983) suggested that, in order to correct the P deficiency of cattle raised on tropical pastures, a mineral mix containing 60 $80 \mathrm{~g} \mathrm{~kg}^{-1} \mathrm{P}$ in its composition should be used and that this mixture ought be provided throughout the year; this recommendation which has almost become a dogma in the production of cattle raised on pastures in Brazil. On the other hand, such generic recommendations do not account for variability between farms and regions of Brazil (Tokarnia et al. 2010; Malafaia et al. 2004, 2014). Other nutrients (energy and protein) and suitable forage mass on offer may be the first limiting and so no response to $\mathrm{P}$ supplementation may occur in this situation (Van Niekerk and Jacobs 1985; Rosa 1993; Malafaia et al. 2014).

The so-called nutritional and clinical examination of the herd is the best way to establish a diagnosis of a mineral deficiency and to supply an economically viable and safe mineral supplement to livestock. The main aspect in the investigation of any problem related to minerals for cattle raised 
on pastures is that professionals must obtain (1) a detailed history about the nutritional and health status of the herd, associated with a careful clinical examination of some animals, and (2) gather data about performance (weight at weaning or age at first parturition), reproduction (fertility rate and calving interval) and, if possible, chemical analysis of animal tissues (Tokarnia et al. 2010). However, the final statement is through experimentation, which consists in giving the suspected or deficient mineral to a group of animals and to compare performance or reproduction parameters with another group that did not receive the mineral in question (Tokarnia et al. 2010; Malafaia et al. 2004).

Mineral supplementation is costly and can range from 10 up to $14 \%$ of the operational costs (ANUALPEC 2013). Although technically feasible, manufacturing and marketing mineral mixtures with less than $40 \mathrm{~g} \mathrm{~kg}^{-1} \mathrm{P}$ is prohibited by Brazilian regulations (BRASIL 2004). Thus, considering the hypothesis that $\mathrm{P}$ levels in commercial mineral supplements can be reduced without affecting animal performance and health, the objective of this experiment was to evaluate the effects of reducing the concentration of $\mathrm{P}$ in the mineral supplement of a typical herd of beef cows on reproductive and productive parameters and the cost of mineral supplementation.

\section{Materials and methods}

This study was carried out in a private farm situated in Agua Clara/MS, Brazil $\left(20^{\circ} 29^{\prime} 56^{\prime \prime} \mathrm{S} ; 52^{\circ} 22^{\prime} 7^{\prime \prime} \mathrm{W}\right)$ during the years 2011 to 2013. The farm, located in the cerrado region, developed an extensive cow-calf system with Nellore cows raised under suitable sanitary control and livestock bookkeeping. The farm used a continuous grazing system where the stock ratio was set depending on the forage mass on offer. Pastures were comprised of signal grass (Urochloa decumbens (Stapf) R. Webster) without any fertilization or soil improvement (Table 1), and the paddocks were about 100 ha with free access to water and troughs for mineral supplementation.

The herd consisted of approximately 1300 cows that had received for several years a commercial mineral supplement

Table 1 Chemical characterization of soil where forage was sampled

\begin{tabular}{ll}
\hline Organic matter $\left(\mathrm{g} / \mathrm{dm}^{3}\right)$ & 13.0 \\
$\mathrm{pH}\left(\mathrm{CaCl}_{2}\right)$ & 4.3 \\
$\mathrm{P} \mathrm{resin}\left(\mathrm{mg} / \mathrm{dm}^{3}\right)$ & 3.1 \\
$\mathrm{~K}\left(\mathrm{mmolc} / \mathrm{dm}^{3}\right)$ & 1.2 \\
$\mathrm{Ca}\left(\mathrm{mmolc} / \mathrm{dm}^{3}\right)$ & 5.0 \\
$\mathrm{Mg}\left(\mathrm{mmolc} / \mathrm{dm}^{3}\right)$ & 7.0 \\
$\mathrm{Al}\left(\mathrm{mmolc} / \mathrm{dm}^{3}\right)$ & 6.0 \\
Base saturation $(\%)$ & 26.1 \\
\hline
\end{tabular}

with $40 \mathrm{~g} \mathrm{~kg}^{-1} \mathrm{P}$ in its composition. In the breeding seasons of 2011, 2012, and 2013, healthy cows in the reproductive phase and aged between 4 and 12 years were randomly divided into two groups and received mineral supplement with $18\left(\mathrm{P}_{18}\right)$ or $40 \mathrm{~g} \mathrm{~kg}^{-1} \mathrm{P}\left(\mathrm{P}_{40}\right)$ (Table 2$)$. The experimental groups were placed on separated signal grass paddocks and managed under continuous grazing system with the stocking rate ranging from 0.4 to 0.6 cows ha ${ }^{-1}$.

The use of $\mathrm{P}_{18}$ supplement was based on previous clinical and nutritional examinations of the herd as recommended by Tokarnia et al. (2010) and Malafaia et al. (2014). For both groups, the replacement of mineral supplements was done weekly or when the troughs were nearly empty.

The breeding season (BS) began in September and ended in December. The bulls were placed in the group of cows at a ratio of 1:25, always ensuring similar age and weight to minimize disturbances linked to the hierarchy of leadership among males.

Before the start of the experiment, from July 2009 to June 2010, the forage was sampled monthly by simulating animal grazing and submitted for chemical analysis of crude protein (CP), neutral detergent fiber (NDF), Ca, $\mathrm{P}$, and $\mathrm{Mg}$. The annual rainfall was recorded and grouped in the 4 months prior to the BS and within 4 months of the BS.

Data on fertility rates (FR) were described in percentage of calves born per cow. There is an important question regarding inferences about FR, because cows cannot be considered as experimental units as they are nested within each pasture of the farm; time, if accounted for, represents a repeated measure taken in the same experimental unit; therefore, year can be accounted for as an additional main classification. However, if cows are not the same within each year, then cows must be nested within year, despite the many variables measured in these animals. Any comparisons need to have true replications for statistical analysis purposes, and in this case, true replicates were absent. In this regard, FR was necessarily computed only as a percentage of total pregnant cows within years. The

Table 2 Composition of mineral mixtures utilized in the experiment

\begin{tabular}{llll}
\hline Element & Units & \multicolumn{2}{l}{ Mineral mixtures } \\
\cline { 3 - 4 } & & $\mathrm{P}_{18}$ & $\mathrm{P}_{40}$ \\
\hline Calcium & $\mathrm{g} \mathrm{kg}^{-1}$ & 45.0 & 82.0 \\
Phosphorus & $\mathrm{g} \mathrm{kg}^{-1}$ & 18.0 & 40.0 \\
Sodium & $\mathrm{g} \mathrm{kg}^{-1}$ & 275.0 & 220.0 \\
Manganese & $\mathrm{mg} \mathrm{kg}^{-1}$ & 500.0 & 500.0 \\
Copper & $\mathrm{mg} \mathrm{kg}^{-1}$ & 2000.0 & 2000.0 \\
Cobalt & $\mathrm{mg} \mathrm{kg}^{-1}$ & 150.0 & 150.0 \\
Zinc & $\mathrm{mg} \mathrm{kg}^{-1}$ & 4.000 & 4.000 \\
Selenium & $\mathrm{mg} \mathrm{kg}^{-1}$ & 10.0 & 10.0 \\
\hline
\end{tabular}


calving interval $(\mathrm{CI})$ of the herd was described in days, and maternal ability was evaluated by the weight of calves at weaning adjusted for 240 days $\left(\mathrm{WW}_{240}\right)$. The interpretation of economic data was made by comparing annual costs considering the use of both types of mineral mixtures $\left(\mathrm{P}_{18}\right.$ and $\mathrm{P}_{40}$ ). The confidence intervals of the means were computed for a confidence level of $95 \%$ by assuming normality of distribution for the random variables sampled.

\section{Results}

There was no apparent relationship between $\mathrm{P}$ levels in either type of mineral supplement and fertility rate of cows (Table 3). Before the start of experiment, the FR average was $88.7 \%$ for 3 years where the mineral supplement $P_{40}$ was utilized and this value was considered as reference for comparison with the FR values obtained during the 3 years of the experimental period, which had an average of 88.9 to $89.4 \%$ for $\mathrm{P}_{40}$ and $\mathrm{P}_{18}$, respectively (Table 3).

As the herd was raised only on pasture, the fertility rates become highly dependent on rainfall, which in turn defines directly the forage mass on offer for cows. The rainfall in the 4 months prior BS and within the BS is shown in Table 4. Another important index that directly affects the reproductive efficiency is calving interval (CI). In this regard, as was observed for the fertility rate, no practical differences were observed in the years 2012 and 2013; but in 2011, there was an apparently anomalous elevated CI for $\mathrm{P}_{40}$ (Table 5).

There were small differences in weight at weaning $\left(\mathrm{WW}_{240}\right)$ for males where their mothers received $\mathrm{P}_{40}$. Interestingly, these same group of cows produced heaviest calves in 2012 and lightest in 2013 (Table 6); but when evaluated in terms of the confidence interval, the average of $\mathrm{WW}_{240}$ for $\mathrm{P}_{40}$ and $\mathrm{P}_{18}$ is within the same population. The reduction in $\mathrm{WW}_{240}$, for males and females in 2011, was a result of the restriction on forage supply to the cows due to severe drought in 2010 (Table 4) that probably reduced body condition score at parturition and consequently compromised milk production.

The average $\mathrm{P}$ in the dry matter of pasture was $1.9 \pm$ $0.45 \mathrm{~g} \mathrm{~kg}^{-1}$ DM (Table 7). McDowell et al. (1983) after
Table 4 Annual and average rainfall of the 4 months before and within breeding season (in $\mathrm{mm}^{3}$ )

\begin{tabular}{llll}
\hline Year & $\begin{array}{l}\text { Annual } \\
\text { Rainfall }\end{array}$ & $\begin{array}{l}\text { Months prior BS } \\
\text { (May, June, } \\
\text { July, Aug) }\end{array}$ & $\begin{array}{l}\text { Months of BS } \\
\text { (Sept, Oct, } \\
\text { Nov, Dec) }\end{array}$ \\
\hline 2008 & 1219 & 52 & 390 \\
2009 & 1461 & 308 & 601 \\
2010 & 1019 & 15 & 488 \\
2011 & 1662 & 47 & 504 \\
2012 & 1621 & 304 & 598 \\
2013 & 1342 & 189 & 463 \\
2014 & 1376 & 134 & 814 \\
Average & 1386 & 149.8 & 551.1 \\
\hline
\end{tabular}

analyzing 1129 samples of different forages from Latin America, found about $73 \%$ of samples containing less than $3.0 \mathrm{~g} \mathrm{P} \mathrm{kg}^{-1} \mathrm{DM}$, and in the same publication the authors described a $P$ requirement ranging from 1.8 up to $4.3 \mathrm{~g} \mathrm{~kg}^{-1}$ DM for beef cattle. Rosa (1993) reported that $72 \%$ of the forage samples had concentrations of P less than $1.2 \mathrm{~g} \mathrm{~kg}^{-1}$ DM.

The differences observed in the average daily consumption (Table 8) are derived of the amount of sodium chloride $(\mathrm{NaCl})$ present in each one of the supplements, which in turn is inversely proportional to $\mathrm{P}$ concentration. Thus, $\mathrm{P}_{40}$ supplement with smaller amount of $\mathrm{NaCl}$ in its composition and a larger concentration of $\mathrm{P}$ was the most expensive per kilogram, the most consumed and generated the greatest expense to the farmer (Table 8). Assuming a relative expenditure of $100 \%$ for the formula with $\mathrm{P}_{40}$, it can be seen that using the $\mathrm{P}_{18}$ supplement, there was a reduction in annual costs of about 37.6 percentage units (Table 8 ).

\section{Discussion}

The hypothesis that the decrease in $\mathrm{P}$ concentration in mineral supplementation did not alter the reproductive parameters was confirmed in this experiment that investigated over 3 years a larger number of cows submitted to a $\mathrm{P}_{18}$ mineral supplement (Table 3). The fertility rate and doses of semen/pregnant cow
Table 3 Fertility rates of beef cows submitted to different phosphorus concentrations in mineral supplements

\begin{tabular}{|c|c|c|c|c|c|c|c|c|c|c|c|}
\hline & \multirow[b]{2}{*}{2008} & \multirow[b]{2}{*}{2009} & \multirow[b]{2}{*}{2010} & \multicolumn{6}{|c|}{ Experimental period } & \multirow[b]{2}{*}{2014} & \multirow[b]{2}{*}{2015} \\
\hline & & & & 2011 & & 2012 & & 2013 & & & \\
\hline Mineral mix & $\mathrm{P}_{40}$ & $\mathrm{P}_{40}$ & $\mathrm{P}_{40}$ & $\mathrm{P}_{18}$ & $\mathrm{P}_{40}$ & $\mathrm{P}_{18}$ & $\mathrm{P}_{40}$ & $\mathrm{P}_{18}$ & $\mathrm{P}_{40}$ & $\mathrm{P}_{18}$ & $\mathrm{P}_{18}$ \\
\hline Total of cows & 1562 & 1424 & 1146 & 437 & 425 & 338 & 342 & 273 & 255 & 1125 & 1182 \\
\hline Pregnant cows & 1430 & 1262 & 984 & 393 & 380 & 304 & 303 & 242 & 226 & 986 & 1014 \\
\hline Fertility rate (\%) & 91.6 & 88.6 & 85.9 & 89.9 & 89.4 & 89.9 & 88.6 & 88.7 & 88.6 & 87.6 & 85.8 \\
\hline
\end{tabular}


Table 5 Calving interval (CI) of beef cows in signal grass pasture with access to two phosphorus concentrations in a mineral supplement

\begin{tabular}{|c|c|c|c|c|c|c|c|c|c|c|c|}
\hline \multirow{3}{*}{$\frac{\text { Years }}{\text { Mineral mix }}$} & \multirow{3}{*}{$\begin{array}{l}2008 \\
P_{40}\end{array}$} & \multirow{3}{*}{$\begin{array}{l}2009 \\
P_{40}\end{array}$} & \multirow{3}{*}{$\begin{array}{l}2010 \\
\mathrm{P}_{40}\end{array}$} & \multicolumn{6}{|c|}{ Experimental period } & \multirow{3}{*}{$\begin{array}{l}2014 \\
P_{18}\end{array}$} & \multirow{3}{*}{$\begin{array}{l}2015 \\
P_{18}\end{array}$} \\
\hline & & & & \multicolumn{2}{|l|}{2011} & \multicolumn{2}{|c|}{2012} & \multicolumn{2}{|l|}{2013} & & \\
\hline & & & & $\mathrm{P}_{40}$ & $\mathrm{P}_{18}$ & $\mathrm{P}_{40}$ & $\mathrm{P}_{18}$ & $\mathrm{P}_{18}$ & $\mathrm{P}_{18}$ & & \\
\hline CI (days) & 354 & 383 & 359 & 403 & 377 & 373 & 360 & 379 & 374 & 379 & 362 \\
\hline $\begin{array}{l}\text { Confidence interval } \\
\text { (days) }\end{array}$ & 9.8 & 8.9 & 7.9 & 12.7 & 9.9 & 9.8 & 8.9 & 12.1 & 14.2 & 12.1 & 11.2 \\
\hline
\end{tabular}

were also similar when beef cows raised on signal grass received only a supplement of sodium chloride instead of the commercial mineral supplement (Peixoto et al. 2003). It was also observed that beef cows reared on koronivia grass (Urochloa humidicola) pastures and supplemented with sodium chloride plus trace elements or a supplement with $111 \mathrm{~g} \mathrm{~kg}^{-1} \mathrm{P}$ showed no difference in reproductive parameters during 6 years of evaluation (S'Thiago et al. 2000). The present results and the studies of Peixoto et al. (2003) and S'Thiago et al. (2000) do not support the recommendation of McDowell et al. (1983) and indicate that there is no association between $\mathrm{P}$ content in mineral supplements and good reproductive parameters when adequate forage mass is available to the cows. Call et al. (1978) found no beneficial effects in reproduction of beef heifers after 2 years of evaluation, when they were provided supplements with $\mathrm{P}$ concentration $66 \%$ lower and $172 \%$ higher than the value recommended by the NRC.

Thus, if the proposal to make a mineral supplementation based on clinical and nutritional diagnosis of the herd was wrong, it would be expected that, after 3 years of experimental evaluation and in 2014 and 2015, the supplementation with the mixture containing lower concentration of $\mathrm{P}$ should affect negatively reproductive parameters; a fact that was not observed.

$\mathrm{WW}_{240}$ is critical in the cow-calf system, because at that time, the first data about calf development are obtained and it is possible to evaluate maternal ability of cows. Therefore, $\mathrm{WW}_{240}$ is highly dependent on an adequate nutritional status of the cows and of the health and genetic potential of the calves. For this reason, $\mathrm{WW}_{240}$ was used as a parameter for the detection of a possible subclinical mineral deficiency in the cows in this study. Weights of beef calves were similar when cows received different $\mathrm{P}$ supplementations in South Africa (De Waal et al. 1996) suggesting that there may have been mobilization of bone $P$ reserve by the cows. According to Van Niekerk and Jacobs (1985) P supplementation of cows did not interfere with intake, body weight, and productive indexes of British breed calves when their mothers were not properly fed with energy and protein, the main nutrients to the cows.

Valk et al. (2002) concluded that high producing dairy cows subjected to lower $\mathrm{P}$ intake maintain lactation during the first year of restriction, however, reduce dry matter intake and milk production from the second year on. In this situation, there may be depletion of body $\mathrm{P}$ reserves and phosphorus deficiency becomes more evident. According to this premise, the $\mathrm{WW}_{240}$ of the calves in this experiment should be reduced over time if the $\mathrm{P}$ ingested from the pasture and from the $\mathrm{P}_{18}$ supplement were not able to meet the requirements of cows. This reduction in $\mathrm{WW}_{240}$ was not consistently observed during the experimental period or when $\mathrm{P}_{18}$ was used in 2014 for all cows of the farm (Table 6).

As pointed out by Tokarnia et al. (2010) and by Malafaia et al. (2004, 2014) soil and forage analysis should not be the only criteria to determine $\mathrm{P}$ status of a herd; this procedure is less important than the clinical and nutritional examination of the herd. According to the NRC (1984). P concentration found in forage (Table 7) would not meet the requirements of lactating $\left(6 \mathrm{~kg} . \mathrm{d}^{-1}\right)$ beef cows, which was recorded as $2.3 \mathrm{~g} \mathrm{~kg}^{-1}$ DM. However, the NRC (2000) recommends that requirements of those animals are met when the $\mathrm{P}$ concentration in the forage is from $1.8-2.0 \mathrm{~g} \mathrm{~kg}^{-1} \mathrm{DM}$. In Brazil, the main
Table 6 Weight at weaning $\left(\mathrm{WW}_{240}\right)$ of beef cows in signal grass pasture with access to two phosphorus concentrations in a mineral supplement

\begin{tabular}{|c|c|c|c|c|c|c|c|c|c|c|c|}
\hline \multirow{3}{*}{$\frac{\text { Years }}{\text { Mineral mix }}$} & \multirow{3}{*}{$\begin{array}{l}2008 \\
P_{40}\end{array}$} & \multirow{3}{*}{$\begin{array}{l}2009 \\
P_{40}\end{array}$} & \multirow{3}{*}{$\begin{array}{l}2010 \\
\mathrm{P}_{40}\end{array}$} & \multicolumn{6}{|c|}{ Experimental period } & \multirow{3}{*}{$\begin{array}{l}2014 \\
\mathrm{P}_{18}\end{array}$} & \multirow{3}{*}{$\begin{array}{l}2015 \\
P_{18}\end{array}$} \\
\hline & & & & \multicolumn{2}{|c|}{2011} & \multicolumn{2}{|l|}{2012} & \multicolumn{2}{|c|}{2013} & & \\
\hline & & & & $\mathrm{P}_{40}$ & $\mathrm{P}_{18}$ & $\mathrm{P}_{40}$ & $\mathrm{P}_{18}$ & $\mathrm{P}_{40}$ & $\mathrm{P}_{18}$ & & \\
\hline $\mathrm{WW}_{240}$ (male) & 219 & 210 & 221 & 194 & 195 & 208 & 219 & 218 & 210 & 208 & 212 \\
\hline $\mathrm{CI}^{\mathrm{a}}(\mathrm{kg})$ & 5.5 & 6.3 & 4.1 & 5.8 & 6.4 & 7.1 & 6.7 & 8.9 & 7.8 & 13.3 & 10.1 \\
\hline $\mathrm{WW}_{240}$ (female) & 192 & 191 & 201 & 178 & 177 & 196 & 199 & 192 & 193 & 190 & 189 \\
\hline CI (kg) & 6.2 & 4.9 & 5.4 & 6.7 & 6.9 & 9.8 & 8.4 & 8.7 & 9.9 & 6.8 & 11.8 \\
\hline
\end{tabular}

${ }^{\mathrm{a}}$ Confidence interval 
Table 7 Chemical composition (in $\mathrm{g} \mathrm{kg}^{-1} \mathrm{DM}$ ) of signal grass

\begin{tabular}{lllllllllllllll}
\hline \multicolumn{10}{c}{2009} & \multicolumn{10}{c}{2010} \\
\hline & Jul & Aug & Sep & Oct & Nov & Dec & Jan & Feb & Mar & Apr & May & Jun & Mean & SD \\
CP & 75 & 64 & 66 & 70 & 71 & 83 & 98 & 96 & 83 & 75 & 62 & 70 & 76 & 11 \\
NDF & 768 & 790 & 765 & 770 & 701 & 791 & 721 & 773 & 706 & 699 & 731 & 747 & 747 & 33 \\
P & 1.8 & 2.0 & 1.1 & 1.6 & 1.4 & 2.5 & 2.8 & 2.6 & 2.1 & 1.6 & 1.9 & 1.5 & 1.9 & 0.45 \\
Ca & 3.2 & 5.8 & 4.7 & 4.8 & 3.9 & 5.1 & 4.4 & 5.0 & 4.9 & 3.5 & 4.2 & 3.8 & 4.4 & 0.71 \\
$\mathrm{Mg}$ & 2.8 & 3.0 & 2.5 & 2.9 & 3.6 & 4.2 & 3.4 & 3.2 & 3.6 & 2.9 & 2.6 & 3.3 & 3.2 & 0.53 \\
\hline
\end{tabular}

aspect that prevents or even limits the response to $\mathrm{P}$ supplementation is a quantitative restriction of forage supply to the animals, commonly seen on farms during the dry season; the qualitative part (crude protein and energy content) is most often secondary to quantitative restriction in the forage mass on offer (Malafaia et al. 2004, 2014).

Costs composition of cow-calf systems under pasture condition, the most prevailing model in farms of Brazil, has as one of its main components the mineral supplementation. As $\mathrm{P}$ is the most important item in the cost of a mineral supplement, it becomes clear that if there is a rational use of $\mathrm{P}$, based on previous clinical nutritional examination of the herd, and by the constant and qualified technical assistance, there will be a significant difference in operational costs, with reduction of concentration of $\mathrm{P}$ in the mineral supplement. Malafaia et al. (2004) found a substantial reduction in costs and no adverse effects on health or weight gain when beef cattle were supplemented with $\mathrm{P}$ levels of $\mathrm{P}_{21}$ or $\mathrm{P}_{25}$.

From a practical point of view, a supplementation with high concentrations of $\mathrm{P}$, is a waste if in excess of requirement and if made without the knowledge of nutritional and clinical examination of herds and a constant technical assistance, can represent an unnecessary cost for livestock production. Additionally, according to several estimates, mineral supplementation may constitute $10-20 \%$ of the operational cost of beef cattle raised in grasslands, which justifies the research studies on the subject in Brazil (Peixoto et al. 2003; Lemos et al. 2013; Malafaia et al. 2004,
2014). This experiment did not test if there would be a response to a zero $\mathrm{P}$ supplementation, but rather tested a reduction in $\mathrm{P}$ concentration, because it was carried out in a private farm which the main objective is to achieve profit. Therefore, based on the absence of clinical signs of deficiency of $P$ in animals, the maintenance of reproductive and productive parameters of the herd and the lowest annual costs with mineral supplementation (Table 8), the farmer and his technical assistance chose to use the $\mathrm{P}_{18}$ supplement for all cows of his farm.

Although technically feasible, manufacturing and marketing mineral mixtures with less than $40 \mathrm{~g} \mathrm{~kg}^{-1} \mathrm{P}$ is prohibited in Brazil. Thus, it is expected that the results of this experiment are further support to other published papers that $\mathrm{P}$ supplementation in Brazil needs to be examined more closely and that the level of $\mathrm{P}$ in supplements would depend on a better identification of those areas where a response to $\mathrm{P}$ would be observed. Phosphorous supplementation for beef cattle in Brazil should always be based on clinical and nutritional examination of the herds and by a constant technical assistance by professionals with solid knowledge on the subject.

\section{Conclusion}

During 3 years of experimentation, in typical conditions of beef cattle production in the Brazilian cerrado, the reproductive parameters of cows and the weight at weaning of calves
Table 8 Absolute and comparative data of the annual costs with mineral supplementation

\begin{tabular}{lll}
\hline & \multicolumn{2}{l}{ Mineral mixtures } \\
\cline { 2 - 3 } & $\mathrm{P}_{18}$ & $\mathrm{P}_{40}{ }^{\mathrm{a}}$ \\
\hline Value of package of $30 \mathrm{~kg}(\mathrm{R} \$)$ & $28.3(76.9 \%)$ & $36.8(100.0 \%)$ \\
Price per kg $(\mathrm{R} \$)$ & $0.94(76.9 \%)$ & $1.23(100.0 \%)$ \\
Intake $(\mathrm{g} /$ day) & $43(82.7 \%)$ & $52(100.0 \%)$ \\
Value of daily intake $(\mathrm{R} \$ /$ day $)$ & $0.040(62.4 \%)$ & $0.064(100.0 \%)$ \\
Annual costs $(\mathrm{R} \$$ /head) & $14.6(62.4 \%)$ & $23.4(100.0 \%)$ \\
Annual cost from 1000 heads $(\mathrm{R} \$)$ & $14,600(62.4 \%)$ & $23,400(100.0 \%)$ \\
Annual cost from 1000 heads $(@)^{\mathrm{b}}$ & 100.7 & 161.4 \\
\hline${ }^{\mathrm{a}}$ Considered as the standard $100 \%$ & & \\
${ }^{\mathrm{b}} \mathrm{R} \$ 145.0 / @$ of cattle in June 2015 & &
\end{tabular}


were not influenced by the reduction of $\mathrm{P}$ concentration in the mineral supplement. However, there was a significant reduction in the annual costs with the mineral supplementation with the formula containing $18 \mathrm{~g} \mathrm{~kg}^{-1} \mathrm{P}$ in its composition.

Acknowledgments The authors wish to thank the family Camargo Rocha for the use of the Santa Terezinha farm and their herd to carry out this experiment and to Robert M. Boddey (Embrapa Agrobiology), Jürgen Döbereiner (Embrapa Animal Health), and Dennis Poppi (U. Queensland) for valuable suggestions and reviewing the English version of the manuscript.

\section{Compliance with ethical standards}

Conflict of interest The authors declare that they have no competing interests.

Statement of animal rights All procedures and animal handling followed the ethical principles of use of the animals in teaching and research of UNESP.

Informed consent Informed consent was obtained from all individual participants included in this study.

\section{References}

ANUALPEC, 2013. Anuário da Pecuária Brasileira. Custo da pecuária intensiva/semi-intensiva em 25 regiões pecuárias. São Paulo, SP: FNP, p.145 - 183.

BRASIL, 2004. MAPA. IN 12 de 30/11/2004. Aprova o regulamento técnico sobre a fixação de parâmetros e das características mínimas dos suplementos destinados a bovinos. Disponível em $<\mathrm{http}$ ://extranet. agricultura.gov.br/sislegisconsulta/consultarlegislacao.

Call, J. W., Butcher, J.E., Blake, J.T., Smart, R.A., Shupe, J.L., 1978. Phosphorus influence on growth and reproduction of beef cattle. J. Anim. Sci. 47, 216-225.
De Waal, H.O., Randal, J. H.R., Koekemoer, G.J., 1996. The effects of phosphorus supplementation on body mass and reproduction of grazing beef cows supplemented with different levels of phosphorus at Armoedsvlakte. S. Afr. J. Anim. Sci. 26, 29-36.

Lemos, G.C., Costa, R.M., Neto, M.G., Malafaia, P., 2013. Desempenho ponderal de bovinos Nelore suplementados com fontes alternativas de fósforo. Pesq. Vet. Bras. 33, 188-192.

Malafaia, P., Peixoto, P.V., Gonçalves, J.C.S., Moreira, A.L., 2004. Ganho de peso e custos em bovinos de corte submetidos a dois tipos de suplementos minerais. Pesq. Vet. Bras. 24, 160-164.

Malafaia, P., Costa, R.M., Brito, M.F., Peixoto, P.V., Barbosa, J.D., Tokarnia, C.H., 2014. Equívocos arraigados no meio pecuário sobre deficiências e suplementação minerais em bovinos no Brasil. Pesq. Vet. Bras. 34, 244-249.

McDowell, L.R., Conrad, J.H., Ellis, G.L., Loosli, J.K. 1983. Minerals for grazing ruminants in tropical regions. University of Florida, Gainesville, 86p.

National Research Council - NRC. 1984. Nutrient requirements of beef cattle: National Academy Press. Washington, D.C

National Research Council - NRC. 2000. Nutrient requirements of beef cattle: National Academy Press. Washington, D.C

Peixoto, P.V., Malafaia, P., Miranda, L.V., Canella, C.C.F., 2003. Eficiência reprodutiva de matrizes bovinas de corte submetidas a três diferentes tipos de suplementação mineral. Pesq. Vet. Bras. 23, $125-130$.

Rosa, I.V., 1993. Deficiências minerais e desempenho reprodutivo de ruminantes. Campo Grande, MS: Embrapa CNPGC, 46 p. Circular Técnica 23.

S'Thiago, L.R.L., Moraes, S.S., Nicodemo, M.L.F., Rosa, I.V., 2000. Efeito do fósforo suplementar sobre o desempenho reprodutivo de vacas de corte em pastagem de Brachiaria humidicola. Pesq. Agrop. Bras. 35, 449-456.

Tokarnia, C.H., Peixoto, P.V., Barbosa J.D., Brito M.F., Döbereiner, J., 2010. Deficiências Minerais em Animais de Produção. Ed.Helianthus, p.19-42, Rio de Janeiro, Brazil.

Valk, H., Sebek, L.B.J., Beyen, A.C., 2002. Influence of phosphorus intake on excretion and blood plasma and saliva concentrations of phosphorus in dairy cows. J. Dairy Sci. 85, 2642-2649.

Van Niekerk, B.D.H., Jacobs, G.A., 1985. Protein, energy and phosphorus supplementation of cattle fed low-quality forage. S. Afr. J. Anim. Sci. 15, 133-136. 